\title{
Students' Perceptions of the Use of Blogs in English Language Learning
}

\author{
Miftachudin \\ IAIN Salatiga \\ Miftac4@gmail.com \\ DOI: http://dx.doi.org/10.18326/rgt.v10i1.101-121
}

\section{ENGLISH ABSTRACT}

This study aims to provide understanding about students' perceptions of the benefits of blogs in English language learning and their challenges in authoring blogs. In addition, this study explores the benefits of blogs in English language learning. Furthermore, it investigates the challenges in authoring blogs that potentially define the gaps between students' perceptions and blogging practice in English language learning. This study involves three undergraduate students at the State Institute for Islamic Studies (IAIN) Salatiga. It is conducted by using two stages of semi-structured interviews through Skype. The findings from the data analysis outline that the students perceive blogs as a beneficial application for English language learning in the areas of writing, reading and communication. However, they also admit that challenges remain in authoring blogs, such as performance fluctuation, self-confidence and aspects of technology. From the findings, there is a suggestion to formulate strategies in order to counteract the challenges. Thus, the use of blogs improves the quality of English language learning in any future practice.

Keywords : students' perceptions, English language learning, benefits of blogs, challenges in authoring blogs.

\section{INDONESIAN ABSTRACT}

Penelitian ini bertujuan untuk memahami persepsi mahasiswa mengenai manfaat blogs dalam pembelajaran bahasa Inggris sekaligus tantangan mereka dalam menggunakan blogs. Tidak seperti website pada umumnya, blogs merupakan aplikasi yang gratis dan sederhana yang bisa digunakan siswa walaupun mereka tidak memiliki kemampuan bahasa komputer. Blog bisa disebut sebagai sebuah lingkungan pembelajaran bahasa Inggris asli yang di dalamnya memungkinkan kegiatan refleksi dan kolaborasi. Selain itu, penelitian ini mengeksplorasi manfaat blogs dalam pembelajaran Bahasa Inggris. Kemudian juga, dalam studi ini mencoba untuk menginvestigasi tantangan-tantangan dalam menggunakan blogs yang kemungkinan dapat bermanfaat untuk memahami perbedaan antara persepsi siswa dengan praktek penggunaan blog dalam pembelajaran Bahasa Inggris. Subjek penelitian ini adalah tiga mahasiswa S1 di IAIN Salatiga. Penelitian ini dilaksanakan dengan menggunakan dua sesi semi-structured interviews melalui Skype. Temuan dari analisa data menyebutkan bahwa siswa menganggap blogs sebagai aplikasi yang bermanfaat untuk pembelajaran bahasa Inggris dalam bidang menulis, membaca, dan komunikasi. Akan tetapi mereka juga mengungkapkan bahwa terdapat tantangan dalam menggunakan blogs seperti fluktuasi kerja,kepercayaan diri dan aspek teknologi. Dari temuan tersebut kemudian memunculkan saran untuk memformulasikan strategi untuk mengatasi tantangan-tantangan tersebut. Sehingga penggunaan blogs akanmeningkatkan kualitas pembalajaran bahasa Inggris di kemudian hari. 
Kata kunci : persepsi siswa, pembelajaran Bahasa Inggris, manfaat blogs, tantangan dalam menggunakan blogs.

\section{INTRODUCTION}

People have been familiar with blogs or weblogs since the emergence of the World Wide Web (Winer, cited in Campbell, 2004). Blogs are online writing spaces that can be edited immediately and published publicly through web browsers (Zhang, 2009). They work as online journals in which blog developers can update any day-to-day life experiences independently (Oravec, 2002). However, according to Blood (2000), the vast use of blogs started around 1999 because the platform was developed to aid web users in some areas. The first point is that users do not need any advanced knowledge of coding, HTML and FTP in order to be pertinent blog developers (Lohnes cited in Ducate \& Lomicka, 2003). Furthermore, users can customise blogs with little difficulty even though they may have very little knowledge of computer language. The second point is that blogs provide free domain and hosting unlike standard websites (Campbell, 2004). As a result, this makes blogs more accessible to everyone.

In educational realms, blogs are popular amongst teachers and students, especially in the field of English language learning (Noytim, 2010). Teachers and students have become more interested in using blogs because blogging activities focus on sharing plain text and commenting on each other posts (Oravec, 2002). Developing personal blogs is motivating for students since they can publish the contents based on their interests. In such situations, blogs elevate learners' interest and ownership because they are independent in authoring and searching for information for their updates (Ferdig \& Trammell, 2004). Moreover, students can upload any form of data such as audio-video files, hyperlinks, pictorial data, colour and text data on blogs (Kress, 2003; Smith \& Baber, 2005; Du \& Wagner, 2007).

The use of blogs is relatively new in education realms and English language learning (Zhang, 2009). There is still little research that focuses on the topic of using blogs in both fields; education and English language learning. Experts in the field of blog technology only provide reports on the function and use of blogs but neglect the benefits of blogs for education (Du \& Wagner, 2007). In English language learning, the incorporation of blogs into course design can actually lead to effective language learning ( $\mathrm{Wu}, 2005)$. Therefore, the study specifically explores the benefits of blogs for English language learning as well as the challenges in authoring blogs. 


\section{Aims}

This study aims to help English language educators gain understanding of the benefits of blogs in English language learning derived from students' perceptions and about the gaps between students' perceptions and blogging practice in English language learning. In the long run, the future practice of blogs in English language learning will be more effective.

In line with that, there are two objectives in this study. The first objective is to determine the benefits of blogs in English language learning to encourage more students to use blogs as an extension of learning outside class. The second objective is to define the challenges in authoring blogs in order to trigger awareness prior to the implementation of blogs in English language learning

\section{Theoretical framework}

Empowering learners' independence in English language learning

Empowering learners' independence is the focus issue in education (Kenny, 1993). Being independent in learners' contexts means learners take control of their own learning, gain more responsibility for any decisions in learning aspects and develop strategies for learning (Sherrin, 1997).

Little (1994) says that the principle of learners' independence also takes place in foreign language learning. Language development is an internal process in which learners need to take account themselves. Therefore, language instructors should not intensively fill learners' time and space during the process of thinking. However, Pinkman (2005) suggests that language instructors need to stimulate and facilitate learners to be independent. As a means of doing this, language instructors can encourage learners to create a new learning environment. Accordingly, learners need to maintain this environment as a learning extension out of the class.

The student-centered approach in English language learning

The idea of learners' independence is incorporated in the student-centered approach that facilitates learners to take responsibility in learning. According to Pinkman (2005, p. 12), "once learners take responsibility for their learning, they will be more able to capitalize on learning environments both in and out of the classroom, hopefully making them life-long and efficient learners". 
Moreover, a student-centered approach is defined "as a broad teaching approach that includes substituting active learning for lectures, holding students responsible for their learning, and using self-paced and/or cooperative (team based) learning” (Felder \& Brent, 1996, p. 43). Such approaches improve learning motivation, enhance learners' appreciation of learning subjects, bring deeper insights and promote more knowledge retention (Bonwell \& Eisen, 1991).

On the other hand, a teacher-centered approach has less impact on the development of students' independence in English language learning. In a teacher-centered approach, students mostly rely on learning input from language instructors which means the instructors actually feed information to students (Clasen \& Bowman, 1974). The instructors are in control of all aspects of the learning process such as learning targets, language materials and exercises, or learning orientations. Consequently, “...this approach appears to minimize continuity in the knowledge acquisition process, reduces reinforcement, and therefore reduces the lasting effect of learning” (Du \& Wagner, 2007, p. 1).

\section{Blogs and English language learning}

Technology possesses lots of advantages in facilitating and complementing English language learning. It is a motivating tool (Ferdig \& Trammell, 2004; Zang, 2009). It allows learners to independently learn, based on their personal interests, develop their own learning strategies and adjust the pace of learning (Blin, 1999).

To gain the advantages offered by technology in English language learning, Pinkman (2004) points out Computer Assisted Language Learning (CALL) as the area with the most potential. Specifically, Pinkman considers blogs as a type of CALL, applications that can potentially facilitate English language learning in an authentic, reflective and collaborative environment beyond the classroom.

Blogs can be used not only to enhance but also to complement language learning in EFL classrooms (Ding, 2008; Cashion \& Palmieri, 2002). Ding (2008) claims that the quality of education can be improved by using blogs. In his research, he finds that through blogging, learners increase their learning interest and initiative in English language learning. Du \& 
Wagner (2007) argue that students' individual English language learning and course achievements are significantly affected by using blog projects.

Furthermore, blogs are popular not only in the field of education but more specifically in that of English language learning (Noytim, 2010). Blogs are significantly used inside and outside the EFL classrooms (Pinkman, 2005). In EFL classrooms, blogs can be utilized as a medium of personal written expression, communication and as a forum of discussion and build relationships in an authentic cyberspace community (Wu, 2005; Pinkman, 2005; Campbell, 2003). They can be utilized to elevate learners' motivation and ownership in English language learning because learners have autonomy in organizing the contents (Ferdig \& Trammell, 2004). 
The types of blogs in English language learning

The types of blogs are diverse including tutor blogs, class blogs and learner blogs which can be integrated into English Foreign Language (EFL) class activities (Campbell, 2003). However, from these three kinds of blogs, students independently take advantage of the use of learner blogs. Learner blogs can be personally or collaboratively managed by students (Oravec, 2002) which is beneficial for students in English language learning (Ding, 2008). Ding (2008, p.33) states "Freedom should be given to students to establish blogs with their own personality. Individual blogging can help students express their distinct individuality in the learning process, stimulating their interest and activating their initiative for the English language learning”.

Thus, at this point, the term 'blogs' is interchangeable with that of 'learner blogs' as the focus of the discussion in this study.

\section{RESEARCH METHODS}

\section{The research approach}

This research is a small-scale study conducted using a qualitative approach. The focus of this research is to explore the students' perceptions around the topic of the use of blogs in English language learning. The exploration will lead to the phenomena and significant description related to research questions. Accordingly, the result of this qualitative research will be a salient gauge to argue and affirm those phenomena.

There are two reasons deploying qualitative approach in this research. Firstly, Creswell (2008) defined that qualitative research as:

"A type of educational research in which the researcher relies on the views of participants; asks broad, general questions; collects data consisting largely of words (or text) from participants; describes and analyses these words for themes; or conducts the inquiry in a subjective, biased manner" (p. 46).

In line with that, this study intends to have an exploration that relies on the students' views. In the first run, the general questions are asked to collate the text data. Then, the data is analyzed to find out the themes. From that rationale, this study can justify that qualitative approach is appropriate for the research study. 
Secondly, Creswell (2008) and Coombes (2001) state that qualitative research typically involves small scale population such as an individual or a few individuals in the process of data collection. In this research, the writer only involves three respondents who are thoroughly investigated. The writer felt, in this light, that three students would be sufficient to address the research questions.

\section{The context}

State Institute for Islamic Studies (IAIN) Salatiga launched the Intensive English Program in 2010. This program consisted of additional English classes for students who lived in campus accommodation in Salatiga. Female and male students were separated into different accommodation and English classes. Related to this research, the context focuses on the English classes which are conducted in Female campus accommodation at the end of even semester of the academic year 2014-2015.

As a pioneering program, it was not graded like other programs on a regular basis. Its objectives were to enhance students' language skills, involve them in a convenient language environment and give them more experience in using language. Moreover, these objectives were related to the diversity of class population. The students of the Intensive English Program came not only from English schools but also from others schools such as Islamic studies, elementary education, Islamic economics, Arabic and Islamic law.

\section{The population and the participants}

Of the 30 students observed, ten students made use of blogs outside of the class. However, only 3 students accepted the request to be participants in this research. Those three students are outlined in the following section.

The participants of this research are three undergraduate students of the Intensive English Program in the State Institute for Islamic Studies (IAIN) Salatiga. In turn, the tables will describe the participants in a brief description. 
Table 1: The personal identification of respondents

\begin{tabular}{ccccl}
\hline No & Name & $\begin{array}{c}\text { University } \\
\text { Major }\end{array}$ & $\begin{array}{c}\text { Blogging } \\
\text { starting date }\end{array}$ & Blog Providers \\
\hline 1 & Respondent 1 & English & 2008 & $\bullet$ Blogger.com \\
& & & 2009 & $\bullet$ Wordpress.com \\
& & & 2011 & $\bullet$ Shvoong.com \\
2 & \multirow{2}{*}{ Respondent 2 } & English & 2010 & $\bullet$ Blogger.com \\
& & & 2011 & $\bullet$ Shvoong.com \\
& \multirow{2}{*}{ Respondent 3 } & Islamic & 2008 & $\bullet$ Blogger.com \\
& & Studies & & \\
& & & 2008 & $\bullet$ Wordpress.com \\
& & & 2011 & $\bullet$ Shvoong.com \\
\hline
\end{tabular}

Table 2: The observation of learners' blog

\begin{tabular}{lccc}
\hline \multirow{2}{*}{ Participants } & \multicolumn{3}{c}{ Articles } \\
\cline { 2 - 4 } & Indonesian & English & Total \\
\hline Respondent 1 & 87 & 5 & 92 \\
Respondent 2 & 8 & 3 & 11 \\
Respondent 3 & 40 & 0 & 40
\end{tabular}

The first participant is studying English and has had experience in authoring blogs since 2008. Initially, she made use of Blogspot from blogger.com in 2008. However, she never posts any articles on it. In the following year, she used Wordpress from worpress.com. In this blog, she only posted several articles. Eventually, she signed up to Shvoong from shvoong.com in 2011. In this blog, she has posted a lot of articles. However, she has not updated this blog since 2012.

The second participant is also studying English. She started her first attempt in authoring a blog in 2010. In that year, she used Blogspot from blogger.com. She admitted that she never updated anything in this blog. In 2011, she made use Shvoong from shvoong.com. She has posted several articles. Nevertheless, she has not posted any new articles since 2012.

The third participant comes from Islamic Studies. She used Blogspot from blogger.com and Wordpress from wordpress.com in 2008. However, she neither posted on nor maintained these blogs. In the following year, she made use Shvoong from shvoong.com. Initially, she wrote many articles in this blog. Nonetheless, she has failed to write a post since 2012.

\section{Data generation tools}

This research occupies semi-structured interview to collate the data. Based on several studies, a semi-structured interview is an appropriate device in qualitative research through which to carry out in-depth exploration of specific social phenomena. Creswell (2008) asserts that the 
semi structured interview can be used as one of the forms of data in qualitative research. In qualitative research, he argues that researchers can use broad and general questions to generate responses from the participants.

"Unlike the structure interview, the interviewer is expected to adapt, modify and add to the prepared questions if the flow of the interview talk suggests it" (Cousin, 2009, p.72).

The semi-structured interview is conducted through synchronous Computer Mediated Communication (CMC) Skype software. Mann \& Stewart (2000) suggested that CMC can be employed in case the respondents are dispersed geographically and cannot be contacted face to face. Although Mann \& Stewart (2000) were questioning whether synchronous communication was equal to face to face communication, the interview keep using Skype as the tools. In the context of IAIN Salatiga, Skype is free and an appropriate technology for the participants. Moreover, they have access to the use of laptops and free internet in the campus accommodation or around the university. Thus, the use of Skype is pertinent for this research.

\section{Research procedures}

The research procedure consists of three steps; data preparation, data collection and data processing. The definition of these three steps are respectively explained in the following.

\section{Data preparation}

Data preparation was the preliminary stage in which the writer constructed the interview questions. At first, three mini tour questions are raised as the opening session to identify the participants. In addition, the writer made outlines for semi-structured interview questions based on the literature review and students' blog observation. By so doing, there are five general questions related to the benefits of blogs as the first stage of the interview session. Probing questions might take place to follow up the participants' responses. The probing questions were the initial sets that they might be modified during the interview to extract more information. Further, the writer also prepared seven questions to explore students' challenges in authoring blogs as the second stage of the session. 


\section{Data collection}

The data are collected through two stages of semi-structured interviews. Whilst the interview proceeded, the conversation was audio recorded, verbatim by using a digital recorder. In the first stage, the writer wanted to explore the first question of the research about students' perceptions of the benefits of blogs in English language learning. The stage consisted of five general questions and several probing questions that are asked during the interview to extract further information.

Simultaneously, the second stage of the interview session is conducted. The objective of this stage was to explore students' challenges in authoring blogs. The writer felt that gaining insights into those challenges would help him understand what gaps there are between learners' perceptions of the benefits of blogs and their blogging practice in English language learning. Overall, the second stage of the interview consisted of seven questions.

\section{Data processing}

The data from the interview was in the form of audio recording. From ethical considerations, the respondents agreed to use Indonesian as the instruction language in communication and interview. Therefore, the data was not only transcribed but also translated into English before the process of analysis. Based on Coombes (2001) explanation, qualitative data is presented mostly in the form of tabulation. Therefore, the writer decided to collate data in tabulated form so that it could be more easily analyzed.

Repetition, filler or idioms were excluded. The writer only translated some parts of the data called extracts. Those extracts were selected and tabulated into a computer file by using Microsoft Word. Coombes (2001) asserts that a word processor is relevant software to produce documents for any research. In addition, data reduction is allowed before the data presentation (Miles and Huberman, 1994). However, Punch (2009) suggests that the deducted data must still be significant and the main components can be used for the analysis.

The data in the second stage of semi structured interview was also treated as the first one. It was transcribed and translated excluding the repetition, filler or idioms. Eventually, it was 
presented in the tabulation by using the same word processor application before the analysis proceeded.

\section{DISCUSSION}

In this section, the writer discusses the findings including three benefits of blogs in English language learning and three challenges in authoring blogs. In the discussion, the writer also correlates the findings with past studies that have been published. Eventually, the conjunction between the findings and the past studies will give reliable answers to the research questions.

\section{Benefits}

\section{Writing}

Campbell (2003) says that the idea of blogs is to promote learner writing practice. Moreover, blogs facilitate learners to have a purpose in writing (Zhang, 2009). Those ideas are in line with the findings of this study. In this study, respondents 1 and 2 have the same perception and practice of blogs for writing in English. However, respondent 3 only perceives that blogs facilitate her to write in English as she is not confident to write in English.

Respondents 1 and 2 focus was to generate an income as their initial purpose for writing blogs. However, in the process, they realized that generating an income from writing blogs was not easy to do. Consequently, they changed their focus from seeking income to selfactualization. On the contrary, respondent 3 has set writing as a major purpose of authoring blogs since she set up blogs. She finds that blogs are another media to facilitate her hobby of writing.

Learners can author and manage their blogs independently or collaboratively to update any thoughts, words and opinions (Oravec, 2002). They may write anything they desire based on their own interest that leads learners to independently direct their learning (Ferdig \& Trammell, 2004). In addition, Ferdig \& Trammell assert that blogs work as an online journal in which learners are capable of updating any life-experience. In this research, the respondents use and manage their blogs independently. They concur that blog facilitates independent writing practice. In addition, they can upload anything based on their preferences. 
Respondent 1 confirms that she can independently articulate her opinions without being frightened that anyone will reject her writing. Meanwhile, respondent 3 applies her independence in authoring blogs into various types of writing such as short stories, diaries, life experiences, summaries of learning materials and abstracts. Furthermore, respondent 2 takes advantage of blogs not only as a space for independent self-expression but also that for knowledge sharing.

Bernstein (2004) confirms that blogs facilitate the development of writing skills through frequent writing. Two respondents; 1 and 3 explicitly perceive that frequent writing by using blogs promotes their writing development. Respondent 2 is the only participant that implicitly mentions development of writing skills through frequent writing. She says that she can improve her writing skills in English because she has more words to write. Through frequent writing, respondent 3 thinks that she can develop her grammar. In addition, she was capable of revising her writing by using blogs. Similarly, respondent 1 also can revise the errors that she may have in her writing. Therefore she recognizes the progress of her writing skills gradually.

\section{Reading}

Pinkman (2005) makes a claim based on his research that blogs potentially enhance learners' reading comprehension. Moreover, Campbell (2003) says that English as a Second Language (ESL) learners mostly take advantage of blogs in reading and writing classes. Their claims emerge in the finding of this research. The respondents agree that blogs have facilitated reading activities. In different terms, they perceive blogs as a beneficial medium that lead them to read more.

Respondent 1 and 2 mostly read blogs to support their assignment as they major in English school. They use information from blogs to generate or refer to ideas in their assignments. On the other hand, respondent 3 reads blogs as references for her creative writing because she is majoring in Islamic Studies and never has any assignments in English. Overall, the respondents concur that reading blogs is a salient method to promote further reading. 
In authoring blog posts, learners experience meaningful learning through website exploration (Zhang, 2009; Campbell, 2004). In line with that, Blood (2002) sorts out three chronological steps in authoring blogs including scouring, filtering and posting. During the scouring process, learners need to find the relevant sites to support their opinions or generate ideas per se. They may occupy search engines to surf thoroughly. Surfing related information can be performed in English. Thus, it will empower students' reading comprehension, increase vocabulary retention and develop more insight on certain topics (Ducate \& Lomicka, 2005; Pinkman, 2005). In this study, the findings affirm the points of website exploration, scouring and filtering processes, vocabulary development and gaining more insight on certain topics.

Respondent 3 needs to explore and find trusted resources containing relevant information. Therefore, she can rely on the information and refer it into her own writing. During the exploration, she does not only gain from the related information but also knowledge of writing structure and diction. Through blog exploration, respondent 1 and respondent 2 learn how to be critical readers to compile appropriate information for their assignments or their blog posts. Moreover, respondent 2 finds new vocabulary and various writing styles from blog exploration. The new vocabulary significantly assists her in reading other blogs. Meanwhile, writing styles guide her in constructing her own writing.

\section{Communication}

Blogs belong to Computer Mediated Communication (CMC) applications which can be used in asynchronous communication (Murray \& Hourigan, 2008). Moreover, blogs serve as convenient media for conversation in which interaction and sharing of learning experiences take place ( $\mathrm{Du} \&$ Wagner, 2007). Blogs can be alternative media to have authentic interactions with online community (Wu, 2005; Ding, 2008). In English language learning, blogs have involved student interaction not only with information systems but also with other global audiences (Oravec, 2002; Noytim 2010). In line with that, the respondents in this study perceive that they can use blogs as a medium to communicate and interact with people online.

The comment feature is a salient tool which makes blogging more communicative and interactive (Wilder \& Merritt, 2004; Pinkman, 2005). The communication and the interaction 
also take place when the respondents in this study develop their blogs. By using comment features, they communicate and build mutual interaction.

Respondent 1 has formulated a strategy to build interaction by using comment features. Firstly, she visits other people's blogs. Afterwards, she writes comments that may trigger the blog developers to visit her blogs. Meanwhile, respondent 3 sometimes has her friend comment on her newest blog posts about the next day's presentation materials. Therefore, she can refine the materials in advance. By this kind of interaction, she has peer-assisted learning that may be useful in developing her language skills if she writes in English. On the other hand, respondent 2 is the person who has the least experience in using comments features for interaction. She has only had one comment so far but she replied directly to it. In general, she affirms that she can use comment features for interaction.

In education, Feldman (2001) suggests that learners can take advantage of the vast use of URLs to improve learning, interaction and communication skills. In line with that, all respondents conclude that sharing links is another way of building interaction. Respondent 1 never leaves the incoming comments without any replies. If she gets halted, she tries to provide book titles or some links for references. Likewise, respondent 2 and 3 mostly share their blog update links with their friends on Facebook. In addition, respondent 3 tags, therefore the links reach more people to read and comment.

In a blog project, Pinkman (2005) found that out of 15 students observed, eight students enjoyed the experience of interaction in blogging with fellow students and respectively had peer-assisted learning. Similarly, the findings in this study also reveal the identical phenomena. The respondents' reactions are varied toward interaction in blogging. Respondent 1 explains that she will be pleased if she gets appropriate feedback to her blog posts. She believes that the blog readers are specific. The readers must be people who really need certain information or have subscribed to her blogs. Thus, they will put appropriate comments. On the other hand, respondent 3 is very excited at finding out that people notice her blog posts. She is eager to read and reply to the comments. Meanwhile, respondent 2 has a neutral stance towards commenting activities. She does not mention her feelings in particular. However, she states that 'This is my obligation to answer what people ask'. 


\section{Challenges}

\section{Performance fluctuation}

$\mathrm{Wu}(2005)$ finds that learners' beliefs and actions in posting articles is not congruent. In his research, $85 \%$ of respondents agree that the idea of posting English articles is good to be implemented in their blogs. However, the quantity of blogs is disappointing. The learners posted less than eight articles in one semester. In fact, the action of posting more articles cannot be performed although the majority of learners believe in the idea. The result from Wu's (2005) research seems to be identical with the findings in this study. The respondents believe that blogs have benefits in language learning. However, they are inconsistent in using and maintaining blogs.

The respondents have signed up to several blogs providers such as Blogspot, Wordpress, Shvoong. However, they did not use and maintain them well. Respondent 1 has used Blogspot and Wordpress since 2008. Afterwards, she never used Blogspot. Similarly, she tried to use Wordpress in 2009 but she just uploaded several articles. Respondent 3 uses Blogspot and Wordpress but has not posted anything. Finally, the respondents have used Shvoong since 2011 but they have not maintained their blogging activity.

Du \& Wagner (2007) and Noytim (2010) mention that time constraints are a reasonable explanation for the continuity of authoring blogs. They find that the learners have to deal with many assignments during the current semester. Similarly, from his research, Pinkman (2005) finds out that two out of 10 learners responded that they will keep posting in their blogs unless the time was unavailable. This pattern also happens in the context of this study. The respondents point out that time constraints have caused their performance fluctuation.

Respondent 1 explains that she does not have much time after her regular classes end because she has to follow her schedule. Respondent 2 and 3 state the common reason that they are busy with their assignments during the week.

Du \& Wagner (2007) and Pinkman (2005) assert that learners are not accustomed to the learner-centred environment that requires individual active involvement beyond the classroom. In this kind of learning environment, learners need to have motivation and 
confidence to present their knowledge, review other learners' practice and find related sources. As learners gain the whole control of blog post configuration, the issues of personal independence and motivation are crucial for learners' persistence in authoring blogs. In line with that, the respondents from this study show the personal independence and motivation which affect their persistence and development of English writing skills.

Respondent 1 says that she will write if she is in a good mood. Similarly, respondent 2 states that 'I am a moody person. I will write if I want to'. Although respondent 3 conveys that she loves writing, she keeps mentioning that she cannot change her mood. She says 'Surprisingly, now I have my own laptop. Still, I cannot focus to develop my blogs'.

Their mood also affects the development in English writing skills. Two respondents; respondent 1 and 2 predominantly write in Indonesian. While, respondent 3 writes only in Indonesian. Their excuse is that they are Indonesian natives therefore it is easier to write in Indonesian. However, in some statements, they explain that the process of writing in English is more complicated. Thus they post more Indonesian articles than English ones.

\section{Self-confidence}

Zhang (2009) asserts that learners challenged the lack of self-confidence in writing their ideas in English. He exemplifies this in discussing the case of the best writer in his project who was not confident at all about his skills in writing. In addition, he also felt uncertain about his comments to his classmates' writing although several students were excited about his advice. Those facts also appear in the findings of this study. However, two respondents; respondent 1 and 3 experienced the challenge of self-confidence to write in English.

Respondent 1 felt insecure with her English. She is afraid of making mistakes in English writing. Likewise, respondent 3 faces the typical challenge. She finds herself not confident with her grammar.

$\mathrm{Wu}$ (2005) finds that her learners confronted the challenge of self-confidence in inviting, reading and commenting on each other blogs. From the feedback responses, those learners admit that 'It's quite a shame to ask someone to read my blog', 'I didn't post a lot articles', 
'I don't have enough confidence to share my ideas with my friends', 'What I write is too personal, so I don't want to share with them', 'I would like to keep my privacy, for I may post some articles that mention my classmates', and 'I think that articles I posted were not good enough"(p. 428). In this study, the respondents also admit that they had identical challenges mentioned by $\mathrm{Wu}$.

Respondent 1 does not share her blog posts because she has no new updates. In addition, she is concerned about comments that are irrelevant to the contents of her blog posts. If she posts personal opinions, she prefers that people read them without commenting. Similarly, respondent 3 will share her updates if she knows the topics well. From respondent 2 point of view, she will share her blog posts if she is competent in the topic areas written.

\section{Aspects of technology}

In the case of lack of technological competence, Pinkman (2005) asserts that some learners experience the complication of understanding the application of blog software. The case relates to the difficulty in uploading images onto learners' blog posts, typing practice or understanding the instruction language in English. In the context of this study, the respondents do not mention that they have a problem in uploading images or typing. However, respondent 1 faces the challenge in understanding the instruction language in English. Thus, she cannot configure her blogs.

Respondent 1 partly has a problem in understanding the instruction language of blogs although she has used blogs since 2008. In addition, respondent 2 and 3 concede that they do not fully have salient knowledge in information technology (IT). Respondent 2 never configures her blogs because she has never learnt how to do that. She said 'I set nothing up. I just write, check and post the articles'. In line with that, respondent 3 concurs that she has her blogs configured.

In terms of limitation of internet access, Ding (2008) points out that personal computer availability significantly affects access in blogging. Learners can utilise university computer labs. Instead they may use any computers in commercial internet cafés outside the university facilities. However, these facilities have less influence in free blogging rather than personal 
computers that are used by students in their spare time. In the findings, only respondent 1 cannot afford to buy a laptop. Therefore, she has a problem in developing her blogs. For the rest of the respondents, they do not have such a problem.

\section{CONCLUSIONS}

\section{Summary of the findings}

This study has found three benefits of blogs in English language learning and three challenges in authoring blogs.

The respondents identically perceive that blogs have three benefits in English language learning. The first benefit is in the area of writing. All respondents share the same perception of using blogs for writing. Although two respondents initially have different purposes in authoring blogs, they finally changed their focus in using blogs for writing. Then, the second benefit is in the area of reading. The respondents agree that blogs have facilitated reading activities. They perceive blogs as a beneficial medium that leads them to read more. Finally, the third benefit is in the area of communication. The respondents perceive that they can use blogs as a medium to communicate and interact with people online.

On the other hand, the students find three challenges in authoring blogs. The first challenge is performance fluctuation. The respondents believe that blogs have benefits in English language learning. However, they are inconsistent in using and maintaining blogs. The second issue is self-confidence. They do not have enough confidence to share their writing and to write in English. The last problem is in relation to technology. They mentioned that they had problems in understanding language instruction, laptop ownership and blog configuration.

\section{Further work}

For further research, there is a need to formulate strategies in how to counteract the challenges in authoring blogs. Those strategies are important guidelines for the continuity of implementation of blogs in my classroom. The result can lead the students to resolve their challenges and become more independent. Concurrently, English language teachers may improve the quality of English language learning both inside and outside of the class. 


\section{REFERENCES}

Bernstein, M. (2004). Do weblogs improve writing?. [online] Available at: http://www.markbernstein.org/Jan0401.html\#note 35302 [Accessed 21 July 2015].

Blin, F. (1999). CALL and the development of learner autonomy. In: R., Debski \& M., Levy Eds.) World CALL: Global perspectives on Computer Assisted Language Learning (pp. 133-148). Lisse: Swets \& Zeitlinger.

Blood, R. (2000). Weblogs: a History and Perspective. [online] Available at: http://www.rebeccablood.net/essays/weblog_history.html [Accessed 28 May 2015].

Bonwell, C. C. \& Eison, J. A. (1991). Active learning: Creating excitement in the classroom. ASHE-ERIC Higher Education Report. [online] Available at: http://www.oid.ucla.edu/about/units/tatp/old/lounge/pedagogy/downloads/activelearning-eric.pdf [Accessed, 1 August 2015].

Campbell, A. P. (2004). Using Live Journal for authentic communication in EFL classes. The Internet TESL Journal, 10(9). [online] Available at: http://iteslj.org/Techniques/Campbell-LiveJournal. [Accessed 21 July 2015].

Campbell, A.P. (2003). Weblogs for Use with ESL Classes. The Internet TESL Journal, 9(2), p. 1-4.

Cashion, J., \& Palmieri P. (2002). Relationships on the line. [online] Available at: http://ausweb.scu.edu.au/aw02/papers/refereed/quayle/paper.html [Accessed 30 July 2015].

Clasen, R. E. and Bowman, W. E. (1974). Toward a student-centred learning focus inventory for junior high and middle school teachers. Journal of Educational Research, 68(1), 911.

Coombes, H. (2001). Research Using IT. New York: Palgrave.

Cousin, G. (2009). Researching Learning in Higher Education. New York: Routledge.

Creswell, J. W. (2008). Educational Research: Planning, Conducting, and Evaluating Quantitative and Qualitative Research. New Jersey: Pearson.

Ding, Z. (2008). Application of Blog to English Language Teaching in China. [online] Available at: http://ieeexplore.ieee.org/stamp/stamp.jsp?tp=\&arnumber=4722835 [Accessed 1 July 2015]. 
Du, H. and Wagner, C. (2007). Learning with Weblogs: Enhancing Cognitive and Social Knowledge Construction. IEEE Transactions on Professional Communication, 50(1), p. $1-16$.

Ducate, L. and Lomicka, L. (2005). Exploring the Blogosphere: Use of Web Logs in the Foreign Language Classroom. Foreign Language Annals, 38(3), p. 410-421.

Felder, R. M. and Brent, R. (1996). Navigating the bumpy road to student-centered instruction. College Teaching, 44(2), p. 43-47.

Feldman, S. (2001). The link, and how we think: Using hypertext as a teaching and learning tool. International Journal of Instructional Media, 28(2), p. 153-159.

Ferdig, R. and Trammell, K. (2004). Content delivery in the 'blogosphere'. T.H.E. Journal. [online] Available at: http://defiant.corban.edu/jjohnson/pages/Teaching/BloggingBlogosphere.pdf [Accessed 1 July 2015].

Little, D. (1994). Autonomy in language learning. In: Swarbrick, A. (Ed). Teaching modern languages. Routledge: London, p. 81-87.

Lohnes, S. (2003). Weblogs in education: Bringing the world to the liberal arts classroom. In: L., Ducate \& L., Lomicka. Exploring the Blogosphere: Use of Web Logs in the Foreign Language Classroom. Foreign Language Annals, 38(3), p. 410-421.

Mann, C. \& Stewart, F. (2000). Internet Communication and Qualitative Research: A Handbook for Researching Online. London: Sage.

Miles, M.B. \& Huberman, A.M. (1994). Qualitative Data Analysis. 2nd Edition. Thousand Oaks: Sage.

Murray, L. and Hourigan, T. (2008). Blogs for Specific Purposes: Expressivist or Sociocognitivist Approach?. ReCall 20(1), p. 82-97.

Noytim, U. (2010). Weblogs Enhancing EFL Students' English Language Learning. Procedia - Social and Behavioral Sciences, 2(20), p. 1127-1132.

Oravec, J. A. (2002). Bookmarking the World: Weblog Applications in Education. Journal of Adolescent \& Adult Literacy, 45(7), p. 616-621.

Pinkman, K. (2005). Using Weblogs in the Foriegn Language Classroom: Encouraging Learner Independence. Available at: http://www.jaltcall.org/journal/articles/1_1_Pinkman.pdf [Accessed 28 May 2015]. 
Punch, K. F. (2009). Introduction to Research Methods in Education. London: Sage.

Wilder, H. and Merritt, T. (2004). Weblogs in Language Arts Instruction. In: R., Ferdig et al. (Eds.). Proceedings of Society for Information Technology \& Teacher Education International Conference 2004, p. 3969-3973.

Winer, D. (2002). The history of weblogs. In: A.P., Campbell, (Ed). Weblogs for Use with ESL Classes. The Internet TESL Journal, 9(2), p. 1-4.

Wu, W. (2005). Using Blogs in an EFL Writing Class. [online] Available at: http://people.chu.edu.tw/ wswu/publications/papers/book_chapters/01.pdf [Accessed 20 May 2015].

Zhang, D. (2009). The Application of Blog in English Writing. Journal of Cambridge Studies, 4(1), p. 64-72. 